\title{
Consumption practices and perception of ready-to-eat food among university students and employees in Kuala Lumpur, Malaysia
}

\author{
${ }^{1}$ Basurra, R.S., ${ }^{2,3}{ }^{*}$ Tunung, R., ${ }^{1}$ Kavita, C., ${ }^{2}$ Ribka, A., ${ }^{4}$ Chandrika, M. and ${ }^{5}$ Ubong, A. \\ ${ }^{1}$ Faculty of Applied Sciences, UCSI University Kuala Lumpur Campus, Taman Connaught, Cheras 56000 \\ Kuala Lumpur, Malaysia \\ ${ }^{2}$ Faculty of Humanities, Management and Science, Universiti Putra Malaysia Bintulu Sarawak Campus, \\ Nyabau Road, 97008 Bintulu, Sarawak, Malaysia \\ ${ }^{3}$ Institut Ekosains Borneo, Universiti Putra Malaysia Bintulu Sarawak Campus, Nyabau Road, 97008 \\ Bintulu, Sarawak, Malaysia \\ ${ }^{4}$ Faculty of Medicine and Health Sciences, University Malaysia Sabah, Jalan UMS, 88400 Kota Kinabalu, \\ Sabah, Malaysia \\ ${ }^{5}$ Faculty of Food Science and Technology, Universiti Putra Malaysia, 43400 Serdang, Selangor, Malaysia
}

\author{
Article history: \\ Received: 15 July 2020 \\ Received in revised form: 13 \\ August 2020 \\ Accepted: 14 September 2020 \\ Available Online: 3 January \\ 2021
}

Keywords:

Food safety,

Consumption practices,

Perception,

University,

Ready-to-eat

DOI:

https://doi.org/10.26656/fr.2017.5(1).357

\begin{abstract}
The purpose of the study was to examine the consumption practices and perception of ready-to-eat food among university students and employees in Kuala Lumpur, Malaysia. Through random sampling, a total of ninety-three respondents participated by answering questionnaires. The results showed that majority of the respondents (52\%) consumed RTE food two to four times a week, and most of them (44\%) consumed RTE food during lunch. The biggest motivator for the respondents to purchase RTE food was convenience (46\%). It could be highlighted that majority of the respondents felt that fast-food restaurants to be very safe (11.8\%), and that street foods to be very risky (34.4\%). Most of the respondents were very worried about human spread diseases (such as Hepatitis B) and human spread bacteria (such as E. coli) when buying food (43\%). When buying RTE food, consumers were most concerned about the cleanliness of the store they were buying their food from (66.7\%). The present study indicated that university students and employees showed food safety awareness and concerns especially regarding RTE food. This study could benefit food marketers, and also public health organizations in their efforts to develop more effective education and dissemination of information to the public.
\end{abstract}

\section{Introduction}

Over the last few decades, there has been a noticeable change in developing countries, where readyto-eat (RTE) foods are being vastly consumed by a huge number of people (Almualla et al., 2010). RTE foods are foods consumed without any processing or preparation. These foods could be traditionally or industrially processed, packaged, or unpackaged and are usually considered to comprise, mainly, the publicly vended foods consumed immediately or later (FAO and WHO, 2004; Makinde et al., 2020). RTE foods, such as cooked meats and poultry, cold vegetable dishes in sauce, and fried rice, are very popular as they are intended for direct consumption (Yu et al., 2020). Many people's lifestyles today have led to a great demand for such convenience food products (Brunner et al., 2010). The increased demand for products and services associated with fast- paced city living, particularly products that are convenient and time-saving, is due to the rising number of urban populations too. In addition, there is a growing number of retail food outlets that serve fast and convenient food to meet consumers demand (Osman et al., 2014).

There are many factors that influence ready-meal demand: ageing of the population, changes in family structure, women participation in the workforce, longer working hours, consumer prosperity, desire to proceed to healthy foods, individualism, decrease in cooking skills, and desire to spend less time and efforts in meal-related activities, such as shopping, preparing and cleaning foods. Other factors that are of major influence are such as family size, income level, and work regime (Siekierski et al., 2013). However, with the growing consumption of RTE foods, there are challenges and issues faced by 
public health. Many food poisonings outbreaks which have occurred in Malaysia have been linked to the consumption of RTE foods, such as meat, poultry, fried rice and noodles. Lee et al. (2017) stated that Malaysia recorded 49.79 cases of food poisoning per 100,000 population in 2014 , and approximately $43 \%$ of the total foodborne poisoning incidents in Malaysia were contributed by outbreaks in academic institutions. In most cases, the causes of the contamination were inappropriate storage, unhygienic food preparation area, unhygienic personnel, or inappropriate food handling practices (Soon et al., 2011).

Part of the problem in Malaysia could be due to the consumers' lack of knowledge, and to what extent do the consumers are aware of food safety and support food safety development and implementation. Previous studies have argued that consumers' beliefs, attitudes, and knowledge of food safety can influence behaviours and practices, thus help in solving problems concerning foodborne illnesses (Beier et al., 2004; Bhat and GómezLópez, 2014). These include being updated with food safety rules, federal inspections and more regulatory oversight being done (Fleet and Fleet, 2009). Understanding consumers' knowledge and perception to various food safety issues are crucial for effective development and implementation of food safety policy and risk communication (Frewer et al., 2007).

Thus, the present study is aimed to determine the consumption practices and perception of RTE foods among university students and employees. The two groups were chosen, as a majority of consumers of RTE food are from the younger generation especially students and working people (Meenambekai and Selvarajan, 2012). Also, similar groups (employees and students) were targeted in similar studies (Unklesbay et al. 1998; Haapala and Probart 2004; Fleet and Fleet 2009; Turnbull-Fortune and Badrie, 2012). This study could give an insight into the practices and perception of the general consumers, mainly university students and employees, in Kuala Lumpur, Malaysia.

\section{Materials and methods}

The survey instrument was developed based on previous studies (Fleet and Fleet, 2009; Bae et al., 2010; Alrabadi et al., 2013). The questionnaire consisted of three parts; to assess the demographic profile of the respondents, their RTE food consumption practices, and their perception towards RTE food. A pilot test was performed with 15 students and employees at UCSI University, Kuala Lumpur South Wing Campus. Based on the results, the questionnaire was modified.
The finalized questionnaires were distributed to 125 respondents (after sample size calculation), randomly to two chosen groups (students and employees) at UCSI University. The questionnaires were distributed through an online platform (Google forms and email), as it is comparatively low cost and fast completion time (Gao and Schroeder, 2009). After 3 months, out of 125, a total of 93 questionnaires were successfully collected and applied for data analysis, resulting in a response rate of $74.4 \%$.

Data were analysed using IBM SPSS Statistics 21 by using frequency and percentage mean. Ethical approval for this study was obtained from UCSI University Ethics Committee. Informed consents were sought from all participants. The assurance of anonymity and confidentiality was maintained throughout the study.

\section{Results and discussion}

The purpose of this study was to assess the consumption practices and perception among students and employees at UCSI University, Kuala Lumpur. This study could provide insight into consumers' behaviour and perception of RTE food, especially among students and working adults.

The sample characteristics of the respondents were presented in Table 1. Female respondents exceeded the number of male respondents in the present study. Female respondents constituted of $51.6 \%$ of the subjects as against $48.4 \%$ male respondents. A total of $65.6 \%$ of the respondents were students and $34.4 \%$ were employees. The respondents varied in age $(25$ to 29 years old $=$ $35.5 \% ; 18$ to 24 years old $=30.1 \% ; 30$ to 34 years old $=$ $22.6 \%$; above 35 years old $=11.8 \%$ ). A majority of the respondents' academic qualification is Bachelor (54.8\%), followed by postgraduates (35.5\%), Diploma (8.6\%) and high school (1.1\%).

Table 1. Demographic characteristics of the respondents $(n=$ 93)

\begin{tabular}{llc}
\hline Profile & Respondents & Frequency (\%) \\
\hline Gender & Male & $45(48.4)$ \\
& Female & $48(51.6)$ \\
\hline Status & Student & $61(65.6)$ \\
& Employee & $32(34.4)$ \\
\hline Age & 18 to 24 years old & $28(30.1)$ \\
& 25 to 29 years old & $33(35.5)$ \\
& 30 to 34 years old & $21(22.6)$ \\
& Above 35 years old & $11(11.8)$ \\
\hline Academic Qualification & High school & $1(1.1)$ \\
& Diploma & $8(8.6)$ \\
& Bachelor Degree & $51(54.8)$ \\
& Postgraduate & $33(35.5)$ \\
\hline
\end{tabular}


Consumers' consumption practices of RTE food were shown in Table 2. According to the results, almost half of the respondents (52\%) consumed RTE food two to four times a week, followed by $35 \%$ respondents consumed RTE food once a week, 11\% respondents consumed RTE food five to seven times a week, and the least frequency $(2 \%)$ consumed RTE food more than seven times a week. The frequency of consuming RTE food has been rising with a relative importance of convenience and time saving, and this trend was more visible in young consumers (Priyadarshini, 2015). Younger generations are convenience-driven and prefer food that is easy to buy, preserve, prepare and cook (Siekierski et al., 2012). This could be the reason for the high frequency of RTE food purchase among the majority age group of respondents in the present study who are 18 to 29 years old.

Table 2. Consumers' RTE food consumption practices $(\mathrm{n}=$ 93)

\begin{tabular}{|c|c|c|}
\hline Item & Level & $\begin{array}{c}\text { Percentage } \\
(\%)\end{array}$ \\
\hline \multirow{4}{*}{$\begin{array}{l}\text { How many times } \\
\text { do you usually ea } \\
\text { ready-to-eat food } \\
\text { in a week? }\end{array}$} & Once a week & 35 \\
\hline & Two to four times a week & 52 \\
\hline & Five to seven times a week & 11 \\
\hline & More than seven times a week & 2 \\
\hline \multirow{5}{*}{$\begin{array}{l}\text { When do you } \\
\text { usually consume } \\
\text { ready-to-eat } \\
\text { food? }\end{array}$} & Breakfast & 22 \\
\hline & Lunch & 44 \\
\hline & Tea Break & 5 \\
\hline & Dinner & 14 \\
\hline & More than once & 15 \\
\hline \multirow{6}{*}{$\begin{array}{l}\text { What motivates } \\
\text { you to purchase } \\
\text { ready-to-eat } \\
\text { food? }\end{array}$} & Cheaper price & 11 \\
\hline & Convenience & 46 \\
\hline & Taste & 15 \\
\hline & More variety & 4 \\
\hline & Save time for preparation & 22 \\
\hline & Others & 2 \\
\hline
\end{tabular}

Besides that, a majority of the respondents (44\%) consumed RTE food during lunch. This possibly shows that most of the respondents purchased RTE food for full meals or eating out. This concurs to the report by Bae et al. (2010) that consumers purchased RTE foods for full meals. In Malaysia, eating out has increased dramatically among consumers who are more educated, wealthier, have smaller family size, and are urban residents compared to those who are less educated, less affluent, have larger family size, and are rural residents (Siew and Khee, 2007). However, the survey in this study did not highlight whether the consumers purchased full meals or meal components, hence it is worthy to note this for future research, in order to have an insight on consumers' consumption behaviour of full meals or meal components of RTE food (Scholliers, 2015). 22\% of the respondents in the present study consumed RTE food for breakfast, followed by $15 \%$ consuming RTE for more than one of the meals, $14 \%$ consumed RTE food for dinner and another $5 \%$ for tea breaks.

The biggest motivator for the respondents to purchase RTE food was convenience (46\%). This is similar to many other findings which reported convenience as the major factor for RTE purchase among consumers (Chae et al., 2008; Celnik et al., 2012; Priyadarshini, 2013; Anusha et al., 2020). Consumers have longer working hours, spending more time in traffic, longing to maximize their leisure time, hence requiring products and services that support and make their hectic life easier. Lifestyle changes have increased the demand for convenience, therefore as a reaction to such demand, the food industry has expanded its readymeal options (Siekierski et al., 2012). Other factors that motivate the respondents to purchase RTE food are to save time for preparation $(22 \%)$, the food taste $(15 \%)$, cheaper price $(11 \%)$, more variety $(5 \%)$ and other factors such as free food and the food was available when they were outside $(2 \%)$. Factors that can influence the consumers choice of RTE food are flavour, texture, appearance, advertising and a reduction in traditional cooking. Other factors such as rising income level, more global trade, travelling, convenience in preparation and cost-effectiveness are also positively influencing RTE food demands (Priyadarshini, 2015).

The respondents' perception of RTE food were shown in Table 3. When asked about how safe they feel the food sources were, for fast-food restaurants, a majority $(35.5 \%)$ felt it was reasonably safe, followed by feeling unsure (26.9\%). For full-service (dine-in) restaurants, many respondents felt it is reasonably safe (45.2\%), followed by feeling unsure (35.5\%). For local restaurants, most respondents felt unsure (36.6\%) followed by feeling reasonably safe (35.5\%). Meanwhile, for imported food and prepared food in supermarkets/grocery stores, most consumers felt unsure ( $44.1 \%$ and $34.4 \%$ respectively), followed by feeling reasonably safe $(35.5 \%$ and $29.0 \%$ respectively). However, for street foods, a majority felt it is somewhat risky (37.6\%), followed by very risky (34.4\%). From the results, based on the safest and then most risky category, it could be highlighted that majority of the respondents felt that fast-food restaurants to be very safe $(11.8 \%)$, and that street foods to be very risky (34.4\%).

When asked about to what extent were, they worried about insects and rodent droppings when buying food, a majority were very worried $(37.6 \%)$. Most of the respondents were also very worried about ingredients added during manufacture $(31.2 \%)$. A majority of the respondents were also very worried about human spread diseases (such as Hepatitis B) and human spread bacteria 
Table 3. Consumers' perception towards RTE food $(n=93)$

\section{Questions}

Percentage of Responses (\%)

In general, how safe do you feel these food sources are? *
1. Fast-food restaurants
2. Full-service (dine in) restaurants
3. Local restaurants
4. Imported food
5. Prepared food in supermarkets/grocery stores
6. Street foods

To what extent are you worried about the following issues when you buy food? **

1. Insects and rodent droppings

2. Ingredients added during manufacture

3. Human spread diseases (such as Hepatitis B)

4. Human spread bacteria (such as E. coli)

5. Contaminants induced by employees

6. Possible risks from chemical contamination (such as pesticide residues)

What are your concerns when buying ready-to-eat food? ***

1. You pay attention to price

2. You give attention to the ingredients of the product you purchase

3. You give attention to the amount of calories the product contain

4. You pay attention to the cleanliness of the store you purchase your food from

5. You compare the quality of the package of the food products

6. You pay attention to the nutritional value of the product

7. You pay attention to the trade mark or the producer of the product

8. You pay attention to the purchase location

$\begin{array}{llll}1 & 2 & 3 & 4\end{array}$
5

$+$

$\begin{array}{ccccc}4.3 & 21.5 & 26.9 & 35.5 & 11.8 \\ 0 & 12.9 & 35.5 & 45.2 & 6.5 \\ 6.5 & 21.5 & 36.6 & 35.5 & 0 \\ 0 & 10.8 & 44.1 & 35.5 & 9.7 \\ 0 & 26.9 & 34.4 & 29.0 & 9.7 \\ 34.4 & 37.6 & 23.7 & 4.3 & 0\end{array}$


bacteria. When buying RTE food, consumers were most concerned about the cleanliness of the store they were buying their food from. The present study shows that university students and employees, like the general consumers, have increased awareness and concerns about food safety especially regarding RTE food. It is recommended to investigate the possible factors that could influence consumers' consumption practices and perception towards food safety, and also their actual food safety handling practices. This could benefit food marketers, and also public health organizations in their efforts to develop more effective education and dissemination of information to the public.

\section{Conflict of interest}

The authors declare no conflict of interest.

\section{Acknowledgement}

This study was supported by UCSI University, Kuala Lumpur. The authors would also like to thank the consumers who participated in the study.

\section{References}

Almualla, N.A., Laleye, L.C., Abushelaibi, A.A., AlQasemi, R.A., Wasesa, A.A. and Baboucarr, J. (2010). Aspects of the microbiological quality and safety of ready-to-eat foods in Sharjah supermarkets in the United Arab Emirates. Journal of Food Protection, 73(7), 1328-1331. https:// doi.org/10.4315/0362-028X-73.7.1328

Alrabadi, N.I., Al-Masad, M. and Alboqai, O. (2013). Food safety: A study of Jordanian consumers' knowledge and practices. World Applied Sciences Journal, 22(1), 35-40. doi: 10.5829/ idosi.wasj.2013.22.01.2949

Anusha, A.C.S., Tunung, R., Kavita, C., Ribka, A. and Chandrika, M. (2020). Ready-to-eat food consumption practices, food safety knowledge and relation to gender and education level of consumers in Kuala Lumpur, Malaysia. Food Research, 4(5), 1537-1544. https://doi.org/10.26656/fr.2017.4(5).037

Bae, H.J., Chae, M.J. and Ryu, K. (2010). Consumer behaviors towards ready-to-eat foods based on foodrelated lifestyles in Korea. Nutrition Research and Practice, 4(4), 332-338. https://doi.org/10.4162/ nrp.2010.4.4.332

Beier, R.C., Pillai, S.D., Phillips, T.D. and Ziprin, R.L. (2004). Preharvest and postharvest food safety: Contemporary issues and future directions. Iowa, USA: Blackwell Publishing Professional. https:// doi.org/10.1002/9780470752579
Bhat, R. and Gómez-López, V.M. (2014). Practical food safety: contemporary issues and future directions. West Sussex, United Kingdom: John Wiley and Sons, Ltd. https://doi.org/10.1002/9781118474563

Bolek, S. (2020). Consumer knowledge, attitudes, and judgements about food safety: A consumer analysis. Trends in Food Science and Technology, 102, 242248. https://doi.org/10.1016/j.tifs.2020.03.009

Brunner, T.A., Horst, K.V.D. and Siergrist, M. (2010). Convenience food products. Drivers for consumption. Appetite, 55(3), 498-506. https:// doi.org/10.1016/j.appet.2010.08.017

Celnik, D., Gillespie, L. and Lean, M.E.J. (2012). Time scarcity, ready meals, ill-health and the obesity pandemic. Trends in Food Science and Technology, 27(1), 4-11. https://doi.org/10.1016/ j.tifs.2012.06.001

Chae, M.J., Bae, H.J. and Yoon, J.Y. (2008). Consumption practices and selection attributes of the university students on ready-to-eat foods. Korean Journal of Food Service Management, 11, 289-307.

FAO and WHO (Food and Agriculture Organization and World Health Organization of the United Nations). (2004). Risk assessment of Listeria monocytogenes in ready-to-eat foods: Interpretative summary. Retrieved from FAO website: https://apps.who.int./ iris/handle/10665/42874

Fleet, D.D.V. and Fleet, E.W.V. (2009). Food safety attitudes among well-educated consumers. Internet Journal of Food Safety, 11, 88-97.

Gao, Z. and Schroeder, T.C. (2009). Effects of Label Information on Consumer Willingness-to-Pay for Food Attributes. American Journal of Agricultural Economics, 91(3), 795-809. https://doi.org/10.1111/ j.1467-8276.2009.01259.x

Haapala, I. and Probart, C. (2004). Food safety knowledge, perceptions, and behaviors among middle school students. Journal of Nutrition Education and Behavior, 36(2), 71-76. https:// doi.org/10.1016/S1499-4046(06)60136-X

Makinde, O.M., Ayeni, K.I., Sulyok, M., Krska, R., Adeleke, R.A. and Ezekiel, C.N. (2020). Microbiological safety of ready-to-eat foods in lowand middle-income countries: A comprehensive 10year (2009 to 2018) review. Comprehensive Reviews in Food Science and Food Safety, 19(2), 703-732. https://doi.org/10.1111/1541-4337.12533

Meenambekai, R. and Selvarajan, P. (2012). Consumer attitudes toward ready-to-eat packed food items (with special reference to Jaffna Divisional Secretariat Division). Proceedings of $7^{\text {th }}$ International Research Conference on Management 
and Finance (IRCMF 2012). USA: University of Colombo, Faculty of Management and Finance.

Osman, I., Osman, S., Mokhtar, I., Setapa, F., Shukor, S.A.M., Temyati, Z. (2014). Family food consumption: Desire towards convenient food products. Procedia - Social and Behavioral Sciences, 121, 223-231. https://doi.org/10.1016/ j.sbspro.2014.01.1123

Priyadarshini, V. (2015). Purchasing practice of the consumers towards ready to eat food products. Asian Journal of Home Science, 10(2), 290-295. https:// doi.org/10.15740/HAS/AJHS/10.2/290-295

Siekierski, P., Ponchio, M.C. and Strehlau, V.I. (2013). Influence of lifestyles related to eating habits in ready meal consumption: a comparative study between Sao Paulo and Rome. Review of Business Management, 15(48), 325-342. https:// doi.org/10.7819/rbgn.v15i48.1223

Soon, J.M., Singh, H. and Baines, R. (2011). Foodborne diseases in Malaysia: A review. Food Control, 22(6), 823-830. https://doi.org/10.1016/ j.foodcont.2010.12.011

Turnbull-Fortune, S. and Badrie, N. (2012). Perception, attitude and practices to food safety among university students living in residence halls, Trinidad, West Indies. Online International Journal of Food Science, 1(1), 1-11.

Unklesbay, N., Sneed, J. and Toma, R. (1998). College students' attitudes, practices, and knowledge of food safety. Journal of Food Protection, 61(9), 11751180. https://doi.org/10.4315/0362-028X-61.9.1175

Yu, S., Yu, P., Wang, J., Li, C., Guo, H., Liu, C., Kong, L., Yu, L., Wu, S., Lei, T., Chen, M., Zeng, H., Pang, R., Zhang, Y., Wei, X., Zhang, J., Wu, Q. and Ding, Y. (2020). A study on prevalence and characterization of Bacillus cereus in ready-to-eat foods in China. Frontiers in Microbiology, 10, 3043. https://doi.org/10.3389/fmicb.2019.03043 